\title{
Tinjauan Hukum Islam terhadap Kawing Soro' Pada Masyarakat Bugis Kabupaten Bone
}

\author{
Syawaluddin Hanafi, Anita Marwing, Arini Pratiwi \\ Institut Agama Islam Negeri Bone, Institut Agama Islam Negeri Palopo, \\ Sekolah Tinggi Agama Islam Al Furqan Makassar \\ Email: syawaluddin.hanafi9@iain-bone.ac.id; anitamarwing@iainpalopo.ac.id; \\ arinnailah88@gmail.com
}

\begin{abstract}
This study aims to determine the behavior of the Bugis community in Bone Regency in carrying out marriage. The development of marital culture and customs in the Bugis community in bone district, especially in terms of kawing soro' became the main focus of this research. This research is a qualitative research with Islamic law approach. The results of this study found that habits in people's lives that were considered to be full of spiritual meaning became worthless after the existence of some Bugis communities in the district of Bone who performed kawing soro'. On the other hand, kawing soro' becomes compulsory if adultery is feared, in another sense that kawing soro' can be done if there are forced or emergency conditions. The Bugis community in Bone Regency who implements kawing soro' basically wants to carry out the commands of Allah and their Rasul, but it is not understood by the community that couples who do kawing soro', the husband is obliged to pay dowry even though only giving half and the wife may refuse to give the husband's rights like hanging out and having sex before the wife receives the specified dowry introduction.
\end{abstract}

Keywords: Marriage, Buginese Customs, Kawing Soro', Islamic Law

\section{Kawing Soro' in Bugis Society of Bone Regency in Islamic Law Perspective}

\begin{abstract}
Abstrak: Penelitian ini bertujuan untuk mengetahui perilaku masyarakat Bugis di Kabupaten Bone dalam melaksanakan perkawinan atau pernikahan. perkembangan adat-budaya perkawinan dalam masyarakat bugis di kabupaten bone, terkhusus dalam hal kawing soro' menjadi fokus utama dalam penelitian ini. Penelitian ini merupakan penelitian kualitatif dengan pendekatan hukum Islam. Hasil penelitian ini menemukan bahwa kebiasaan-kebiasaan dalam kehidupan masyarakat yang dianggap sarat akan makna spiritual menjadi tidak bernilai setelah adanya sebagian masyarakat Bugis Kabupaten Bone yang melakukan kawing soro'. Di sisi lain, kawing soro' menjadi wajib dilaksanakan apabila dikhawatirkan terjadinya zina, dalam arti lain bahwa kawing soro' bisa saja dilakukan jika ada kondisi yang memaksakan atau darurat. Masyarakat Bugis di Kabupaten Bone yang melaksanakan kawing soro' pada dasarnya ingin melaksanakan perintah Allah dan Rasul-Nya, namun tidak dipahami oleh masyarakat bahwa pasangan yang melakukan kawing soro', sang suami wajib membayar mahar meskipun hanya memberikan separuhnya dan istri boleh menolak memberikan hak-hak suami seperti bergaul dan melakukan hubungan kelamin sebelum istri menerima pendahuluan mahar yang ditetapkan.
\end{abstract}

Kata Kunci: Perkawinan, Adat Bugis, Kawing Soro', Hukum Islam 
Tinjauan Hukum Islam terhadap Kawing Soro’ Pada Masyarakat Bugis Kabupaten Bone

\section{A. Pendahuluan}

Pernikahan atau perkawinan merupakan perintah Tuhan bagi setiap manusia untuk menguatkan keberadaannya sekaligus mempertahankan perkembangbiakan dengan cara yang tepat dan menurut kaidah norma agama, apapun agama dan keyakinan yang dianut. Di sisi lain, laki-laki dan perempuan sebagai manusia memiliki fitrah yang membutuhkan satu sama lain. Tujuan pernikahan adalah untuk mencapai tujuan hidup dan untuk mempertahankan kelangsungan hidup sebagai manusia. Selain itu, pernikahan merupakan ibadah yang paling utama dalam pergaulan masyarakat muslim, sehingga pernikahan bukan saja dipahami sebagai satu jalan untuk membina rumah tangga dan melanjutkan keturunan, akan tetapi pernikahan juga dipandang sebagai cara untuk meningkatkan ukhuwah islamiyah serta memperluas dan menguatkan silaturahmi antar manusia.

Sebagaimana ibadah-ibadah lainnya, pernikahan mempunyai dasar hukum yang kuat yang menjadikannya tuntunan untuk dapat dilakukan umat Islam. Dasar hukum pernikahan dapat diketahui dari firman Allah swt. dalam Q.S. al-Rūm/30: 21, Q.S. al-Nūr/24: 32) dan Q.S. al-Nisā̄'/4: 1, serta hadis Rasulullah saw. yang artinya:

Dari 'Alqamah berkata bahwa ia berjalan bersama 'Abdullah, ia berkata bahwa ia pernah bersama Rasulullah dan bersabda: barangsiapa yang telah sanggup melaksanakan kehidupan suami isteri, hendaklah ia kawin. Maka sesungguhnya kawin itu menghalangi pandangan mata dan memelihara kemaluan. Dan barangsiapa yang tidak sanggup, wajib berpuasa. Maka sesungguhnya puasa adalah perisai baginya (HR. al-Bukhary). ${ }^{1}$

Perkawinan dalam masyarakat Bugis, sebagaimana dalam Islam merupakan hal penting bagi kehidupan sebab perkawinan dianggap bukan sekedar peristiwa yang harus dijalani oleh dua manusia berlainan jenis kelamin akan tetapi perkawinan merupakan proses pelibatan keluarga besar (sompung lolo) dan masyarakat dalam menanggung tanggung jawab bersama, sehingga dimaknai bahwa perkawinan bukan hanya pertautan laki-laki dan perempuan semata, akan tetapi merupakan pertautan atau penyatuan dua keluarga besar pula. Hal ini menyebabkan orang tua dan keluarga memiliki peran penting sebagai penentu dalam melangsungkan perkawinan anaknya.

${ }^{1}$ Rizal Darwis, Hak Nafkah Batin Isteri dalam Perkawinan (Cet. 1; Gorontalo: Sultan Amai Press, 2015), 19-20. 
Perkawinan sebagai sesuatu yang penting, oleh karena itu dalam proses pelaksanaannya mulai dari mammanu'-manu hingga marola tidak sedikit tenaga dan pikiran yang dibutuhkan agar proses tersebut dapat terlaksana dengan baik. Setidaknya ada 3 (tiga) tahapan dalam perkawinan masyarakat Bugis yang harus dilalui, yaitu;

Pertama adalah pra nikah, merupakan tahapan pendahuluan sebelum pesta perkawinan (mappabbotting) dilaksanakan, diantaranya:

1. Mammanu'-manu', secara etimologi berarti burung yang berterbangan kesana kemari dengan tujuan mencari sesuatu. Mammanu'-manu' juga memiliki istilah lain yakni mabbaja laleng, yang diartikan sebagai membuka atau membersihkan jalan. Dalam pengertian ini prosesi Mammanu'-manu' bertujuan untuk mencari tahu keberadaan/status pribadi dan keluarga perempuan/laki-laki yang ingin dijodohkan, baik itu disampaikan dengan tersembunyi atau terang-terangan. Pada tahapan ini, biasanya dilakukan langsung oleh pihak orang tua laki-laki dengan mendatangi atau bertemu dengan orang tua dari pihak perempuan ataupun dilakukan secara sembunyi-bunyi dengan tujuan untuk mendapatkan gambaran detil (profiling) tentang calon pengantin perempuan baik yang berkaitan dengan kepribadian, akhlak (salompena), pergaulan maupun status yang disandangnya, serta yang terpenting adalah untuk memastikan apakah calon pengantin perempuan tersebut belum pernah dilamar atau dipinang sebelumnya oleh orang lain (ipasitaro), dan apakah keluarga calon yang akan dilamar tersebut telah berkeinginan untuk menikahkan anaknya atau belum. ${ }^{2}$ Fase ini menunjukkan bahwa dalam tradisi Bugis, pernikahan menjadi hal yang sakral dan luhur, oleh karena itu dalam proses pencarian pasangan, semua pihak berperan aktif dalam proses pencarian dan penjajakan agar didapatkan calon pengantin yang sesuai dengan kriteria yang ditetapkan.

2. Madduta, artinya menyatakan secara resmi keinginan untuk meminang. Fase ini ditandai dengan keterlibatan keluarga besar dan tokoh masyarakat dari masing masing keluarga mempelai. Masing masing keluarga juga akan diwakili oleh seorang "pebbicara” (juru bicara). "Pebbicara” dari pihak laki-laki biasanya

${ }^{2}$ Muh. Rusli, "Reinterpretasi Adat Pernikahan Suku Bugis Sidrap Sulawesi Selatan," Karsa, Vol. 20, No. 2 (2012): 248. 
Tinjauan Hukum Islam terhadap Kawing Soro’ Pada Masyarakat Bugis Kabupaten Bone

diiringi oleh rombongan berjumlah 10 atau lebih. Proses bertemuanya dua juru bicara ini menandai proses madutta yang berlangsung dengan beberapa rangkaian acara antara lain: mamanu-manu atau proses berbalas pantun dari kedua pebbicara, membahas uang panaik atau dui menre yang merupakan besaran uang belanja yang akan diserahkan dari pihak laki-laki kepada pihak perempuan; penentuan waktu mappenre dui (mengantarkan uang belanja/luang pana'i); dan proses mappenre dui yakni proses pihak laki-laki menghantarkan duit belanja yang telah disepakati sebelumnya. Para tetangga dari pihak perempuan biasanya akan diundang untuk turut menyaksikan proses mappenre dui tersebut. ${ }^{3}$

3. Mappettu ada, artinya menyepakati beberapa hal penting untuk ditetapkan bersama oleh kedua pihak keluarga yang akan melakukan perkawinan dengan disaksikan oleh keluarga besar dan tokoh masyarakat. Biasanya yang dibicarakan adalah hari baik untuk diselenggarakannya akad pernikahan serta resepsi.

4. Mappacci, artinya membersihkan dan/atau mensucikan. Maknanya adalah harapan untuk kebersihan raga dan kesucian jiwa calon pengantin yang akan melangsungkan akad nikah. Kegiatan ini dilakukan pada saat tudampenni (wenni) yakni malah hari sebelum akad nikah dilaksanakan. Dalam pelaksanaan mapacci beberapa komponen yang dipersiapkan, antara lain beras yang telah digoreng kering, lilin yang dinyalakan, tujuh lembar sarung, bantal, dedaunan seperti daun nangka, daun pisang, kelapa, gula merah dan tempat daun inai (daun pacci). Bahan-bahan tersebut dipilih dengan pertimbangan makna dan filosofi yang terkandung di dalamnya. Beras atau dalam bahasa Bugis disebut Benno merupakan representasi makna harapan bahwa kedua mempelai diharapkan menjadi keluarga yang berkembang secara baik, jujur dan bersih; lilin yang dinyalakan sebagai simbol penerangan, sarung atau lipa yang berjumlah tujuh bertujuan untuk menutup tubuh sehingga merepresentasikan harga diri individu, sementara bantal merepresentasikan makna kemakmuran. Adapun daun pisang merepresentasikan siklus pertumbuhan hidup manusia yang senantiasa sambung menyambung dan tidak terputus. Sementara daun nangka dimaknai sebagai cita-cita luhur serta

\footnotetext{
${ }^{3}$ Widyawati, "Makna Tradisi Uang Panai dalam Adat Pernikahan Suku Bugis di Sungai Guntung Kecamatan Kateman Kabupaten Indragiri Hilir Provinsi Riau," JOM FISIP, Vol. 5, Edisi 11 (2018): 8.
} 
tempat menaruh pacci atau disebut dengan appacingeng, menunjukkan makna kesatuan jiwa dan kerukunan berumah tangga. Keseluruhan komponen dipersiapkan dan ditata dalam ruangan dimana proses mapacci berlangsung.

Dalam pelaksanaannya, prosesi mapacci berlangsung dengan calon mempelai duduk di atas laming atau tempat tidur dalam posisi telapak tangan menengadah keatas dan diletakkan di atas tujuh lapis sutera yang telah ditutupi dengan beberapa helai daun nangka. Kondisi tangan menengadah ke atas menandai kesiapan untuk diberi pacci. Para tamu yang telah terdaftar dalam giliran dipanggil satu persatu untuk memberikan pacci kepada mempelai. Para tamu mengoleskan pacci pada telapak tangan mempelai dengan harapan dan doa untuk menyucikan dan membersihkan calon dari hal-hal buruk, kegiatan mapacci selanjutnya diikutkan dengan proses penaburan beras. ${ }^{4}$

Kedua adalah nikah, yaitu hari dilaksanakannya akad nikah atau esso akkalabinengeng. Adapun kegiatan pada tahapan ini adalah:

1. Mappenre botting, artinya mengantarkan pengantin laki-laki ke tempat pelaksanaan akad nikah. Adapun tempat pelaksanaan akad nikah biasanya dilaksanakan di kediaman pengantin perempuan. Banyak pihak yang dilibatkan dan memiliki peran masing-masing dalam kegiatan ini diantaranya pembawa mas kawin atau pabawwa sompa; pendamping pengantin yang terdiri dari dua anak kecil yang biasanya merupakan keluarga pengantin yang disebut dengan passeppi, orang yang bertugas dalam mengurus pakaian pengantin dan biasanya juga bertindak sebagai penata rias atau yang disebut dengan indo botting, pembawa payung pengantin atau pabbawa teddung, pemuda dan pemudi dari pihak pengantin laki-laki yang ditugaskan membawa makanan dalam bentuk kue-kue Bugis dan pernak pernik lainnya yang disebut dengan pattiwi bosara, dan orang yang ditugaskan dalam menuntun pengantin untuk menemui pasangannya setalah akad nikah dilangsungkan, serta beberapa orang sebagai saksi-saksi dan kerabat lainnya.

${ }^{4}$ Nonci, Upacara Pernikahan Masyarakat Bugis (Makassar: CV Aksara, 2006), 32-33. 
Tinjauan Hukum Islam terhadap Kawing Soro’ Pada Masyarakat Bugis Kabupaten Bone

2. Ma'duppa botting, artinya menunggu atau menjemput kedatangan pengantin lakilaki. Para keluarga dan kerabat dekat calon pengantin perempuan akan bertugas untuk menyambut sekaligus menuntun calon pengantin laki-laki menuju tempat pelaksanaan akad nikah dan dalam prosesi penyambutan ini pula dipentaskan tari paduppa .

3. Akad nikah atau kawing/mappakawing; akad nikah yang pelaksanaannya, umumnya dilaksanakan sesuai dengan kaidah-kaidah syariat Islam.

4. Mappasiluka atau mappasikarawa, artinya mempertemukan pengantin laki-laki dengan perempuan dengan mengantarkannya masuk ke dalam kamar pengantin perempuan. Dalam fase ini akan terjadi proses dialog antara pappakarawa (orang yang menuntun) dan memberikan kenang-kenangan kepada penjaga pintu , jika tawaran dan kenang-kenangan diterima maka pintu akan dibuka. Setelah hal tersebut, maka pappakarawa dari masing-masing pengantin akan menuntun pengantin untuk saling menyentuh bagian tubuh pasangannnya. Proses mappasikarawa ini tentu saja memiliki makna khusus, karena dalam setiap bagian tubuh yang disentuh memiliki makna asenu-sennureng yakni harapan baik dan parellau doang atau doa. Sebagai contoh menyentuh telinga dapat diartikan sebagai pengharapan dan doa bahwa suami isteri akan saling mendengarkan pendapat, saling mencium kening diartikan sebagai pengharapan bahwa dalam membina rumah tangga kelak, pasangan ini senantiasa dilandasi dengan kasih sayang.

5. Marellau dampeng, artinya meminta atau memohon maaf dan restu dari kedua orang tua pengantin perempuan. Dalam prosesi ini, pasangan yang telah sah menjadi suami isteri meminta maaf kepada kedua orang tua dengan cara mencium tangan kedua orang tuanya dan dilanjutkan kepada seluruh keluarga dekat yang hadir pada prosesi akad nikah tersebut. Kegiatan marellau dampeng bermakna bahwa anak tidak boleh melupakan jasa-jasa orang tua yang telah melahirkan, membesarkan mereka dan menghindarkan mereka menjadi anak yang madoraka atau durhaka kepada orang tuanya. 
Ketiga adalah kegiatan setelah akad nikah, ada beberapa kegiatan pula yang harus dilaksanakan setelah akad nikah, diantaranya:

1. Mapparola atau mammatoa, yaitu kunjungan balasan yang dilakukan oleh pihak pengantin perempuan ke kediaman pihak pengantin laki-laki. Pelaksanaan mapparola dimulai ketika seluruh prosesi pernikahan telah selesai. Biasanya waktu pelaksanaan dilakukan satu hari atau beberapa hari setelah pesta pernikahan berdasarkan dengan kesepakatan dari kedua belah pihak keluarga. Pada acara mapparola tersebut, pengantin duduk di pelaminan selayaknya pesta pernikahan pengantin perempuan dan berlangsung pada siang hari dan biasanya akan dilanjutkan pada malam hari. Prosesi Mapparola itu sendiri memiliki multi makna diantaranya a.) Penghormatan antar keluarga. Penghargaan dan penghormatan ditunjukkan oleh pihak keluarga pengantin perempuan terhadap keluarga pengantin laki-laku dengan cara mengantar balik pengantin laki-laki ke rumahnya; b.) ajang silaturahmi. Mapparola selain bermakna penghormatan, juga menjadi ajang pertemuan yang khusus antara kedua keluarga mempelai. Dalam kesempatan tersebut kedua keluarga saling berjabat tangan, bercengkerama dalam suasana kekeluargaan yang kental dan santai, yang tidak memungkinkan terjadi apabila dilakukan pada saat sebelum acara pernikahan atau pada saat pesta pernikahan berlangsung. Dengan keadaan tersebut, maka akan terjadi penyatuan tidak hanya antara dua insan, yakni mempelai laki-laki dan perempuan tetapi juga penyatuan dua keluarga besar; c.) Pengendalian sosial. Dalam masyarakat Bugis, ikatan kekeluargaan teramat kuat bahkan mampu menjadi pengendali sosial bagi anggota keluarganya termasuk dalam menjalani pernikahan. ${ }^{5}$ Ketika keluarga besar hadir dalam acara pernikahan terutama mapparolla,maka kedua keluarga menyadari bahwa adanya tanggung jawab sosial yang mereka emban yakni dengan menjadi bagian dalam kontrol sosial bagi keutuhan dan kelanggengan kehidupan berumah tangga kedua mempelai tersebut.

${ }^{5}$ Rusli, "Reinterpretasi," 252. 
Tinjauan Hukum Islam terhadap Kawing Soro’ Pada Masyarakat Bugis Kabupaten Bone

2. Marola wekka dua, yaitu pengantin perempuan yang sudah mendatangi rumah pengantin laki-laki, baik menginap semalam ataupun tidak, harus kembali lagi ke rumah pengantin perempuan.

Berdasar pada tahapan di atas, kawing atau akad nikah adalah salah satu tahapan kegiatan yang dilaksanakan pada esso akkalabinengeng, adapun kawing yang tidak dilaksanakan pada esso akkalabinengeng atau yang dilaksanakan pada tahapan pra nikah, baik setelah mammanu'-manu' ataupun sebelum mappacci, kawing tersebut diistilahkan oleh masyarakat Bugis sebagai kawing soro'.

Kawing soro' atau akad nikah yang dilaksanakan bukan pada esso akkalabinengeng merupakan realitas perkawinan yang sering terjadi dalam masyarakat Bugis di kabupaten Bone. Masyarakat Bugis di Kabupaten Bone tentunya melaksanakan suatu kegiatan perkawinan yang sudah menjadi kebiasaan dalam kehidupan masyarakat. Kebiasaan-kebiasaan tersebut diyakini memiliki nilai spritualreligius. Jika tahapan di atas diyakini memuat kandungan manfaat, lalu mengapa sebagian masyarakat Bugis di kabupaten Bone melakukan kawing soro? apakah kawing soro' mengenyampingkan tahapan pra nikah? Apakah kawing soro' menghalalkan hubungan suami istri? Atau apa hak dan kewajiban suami dan istri yang melangsungkan kawing soro?

\section{B. Kawing Soro'dalam Masyarakat Bugis di Kabupaten Bone}

Undang-Undang Nomor 1 Tahun 1974 tentang Perkawinan Pasal 1 menyebutkan bahwa perkawinan ialah ikatan lahir batin antara seorang pria dan seorang wanita sebagai suami isteri dengan tujuan membentuk keluarga (rumah tangga) yang bahagia dan kekal berdasarkan ketuhanan Yang Maha Esa; dan Pasal 2 ayat (1) menyatakan bahwa perkawinan adalah sah, apabila dilakukan menurut hukum masing-masing agamanya dan kepercayaannya itu. ${ }^{6}$ Sejalan dengan itu, Kompilasi Hukum Islam (KHI) menyebutkan dalam Pasal 2 bahwa Perkawinan menurut hukum Islam adalah pernikahan yaitu akad yang sangat kuat atau mitsaqan ghalidzan untuk mentaati

${ }^{6}$ Republik Indonesia, Undang-Undang Nomor 1 Tahun 1974 tentang Perkawinan (Jakarta: Alda/Pentja, 1974), 1-2. 
perintah Allah dan melaksanakannya merupakan ibadah; Pasal 3 menyatakan Perkawinan bertujuan untuk mewujudkan kehidupan rumah tangga yang sakinah, mawaddah, dan rahmah. ${ }^{7}$

Adapun perkawinan menurut hukum adat merupakan suatu ikatan antara seorang pria dengan wanita sebagai suami isteri untuk maksud mendapatkan keturunan dan membangun serta membina kehidupan rumah tangga, serta suatu hubungan hukum yang menyangkut para anggota kerabat dari pihak isteri dan para anggota kerabat dari pihak suami. Terjadinya perkawinan, berarti berlakunya ikatan kekerabatan untuk dapat saling membantu dan menunjang hubungan kekerabatan yang rukun dan damai.

Perkawinan atau pernikahan adalah suatu keniscayaan bagi masyarakat Bugis dan merupakan suatu peristiwa penting dalam kehidupannya. Oleh sebab itu, perkawinan dalam masyarakat Bugis di Kabupaten Bone dilangsungkan pada saat semua kerabat dekat (keluarga) ikut terlibat membantu menyiapkan segala hal ikhwal persipan perkawinan dengan tujuan kelancaran acara penting tersebut. Jika dalam pembicaraan dua keluarga pengantin menganggap perlu menikahkan anaknya sebelum esso akkalabineng dan itu disepakati maka dilaksanakanlah kawing soro’.

Pelaksanaan kawing soro' dalam masyarakat Bugis di Kabupaten Bone disebabkan oleh beberapa hal, diantaranya:

\section{Permintaan Khusus Orang Tua (Keluarga Calon Pengantin)}

Pihak keluarga menginginkan agar dilaksanakannya sesegera mungkin kawing soro' sebelum tahapan esso akkalabinengeng adalah adanya faktor-faktor tertentu yaitu: (a) pihak orang tua perempuan yang sedang sakit, dan orang tua merasa khawatir tidak bisa menyaksikan anaknya melangsungkan akad nikah dikarenakan sakit keras; (b) ayah kandung pengantin laki-laki akan kembali pulang ke daerah rantauan tempat dimana ayahnya bekerja (passompe); (c) beberapa orang penting dari kerabat dekat hanya bisa berkumpul diwaktu tertentu, sebab adik atau kakak kandung, dan juga Paman (amaure) dan Bibi (inaure) yang terikat oleh aturan Aparatur Sipil Negara 2004), 1.

${ }^{7}$ Republik Indonesia, Kompilasi Hukum Islam (Jakarta: Mahkamah Agung Republik Indonesia, 
(PNS) tentang masa cuti atau libur, sehingga akad nikah harus dimajukan saat libur Idul Fitri.

Biasanya permintaan untuk kawing soro' tersebut disampaikan oleh pihak keluarga calon pengantin laki-laki ataupun perempuan pada saat tahapan pra nikah madduta dilaksanakan.

\section{Menghindari Perbuatan Zina}

Kekhawatiran terbesar orang tua terhadap anaknya adalah godaan syaitan untuk melakukan perbuatan zina. Orang tua yang memahami anaknya akan mengambil sikap untuk melangsungkan kawing soro' untuk menghindari perbuatan melanggar ketentuan adat dan agama, sebab orang tua mampu dalam pengamatannya untuk memahami anaknya yang sudah saling suka sejak lama dan sudah jalan kemanapun bersama.

Kawing soro' semacam ini bisa saja belum melaksanakan tahapan pra nikah, sebab diketahui anak-anak mereka sudah saling kenal dan mencintai sehingga orang tua hanya menerima dan mengikuti apapun yang diinginkan oleh anaknya, selama itu adalah kebaikan (deceng) dan tidak ada yang dirugikan.

Pada poin ini sebenarnya cukup jelas tergambar bahwa pengaruh hukum agama (hukum Islam) sangat kuat, sebab orang tua menganggap bahwa yang terpenting adalah anak-anak mereka dalam berhubungan itu sah menurut agama.

\section{Hari Baik}

Untuk menentukan hari baik, dalam budaya Bugis, Bissu hadir mengatur segala rangkaian upacara tradisional termasuk dalam acara perkawinan (indo' botting). Bissu mempunyai peranan dan tergolong istimewa sebab dalam kehidupan keseharian masyarakat diperlakukan sebagai satu-satunya perantara komunikasi antara manusia dengan dewa/langit (Basa Torilangi). Akan tetapi setelah Islam masuk dengan perkembangannya yang cukup pesat kemudian menjadi agama resmi kerajaan oleh para penguasa (raja-raja), baik di semenanjung timur sampai ke semenanjung barat Sulawesi membuat bissu terpaksa harus keluar meninggalkan istana kerajaan dan lebih memilih menyatu dengan masyarakat. Saat bissu menyatu dengan masyarakat, yaitu masyarakat Bugis Kabupaten Bone yang modern dan Islami, hingga saat ini keberadaannya masih terlihat dan terlibat pada beberapa acara perkawinan. 
Dalam kehidupan masyarakat Bugis Kabupaten Bone, tatanan dalam kehidupan yang turun temurun harus dijadikan sebagai dasar dalam setiap kegiatan yang akan dilakukan termasuk dalam menentukan hari perkawinan (akad nikah). Perkawinan merupakan sesuatu yang sakral, sehingga dibutuhkan keseriusan dalam pelaksanaannya yang hanya dilaksanakan sekali dalam seumur hidup, keseriusan tersebut menjadi penting untuk pihak keluarga pengantin selektif dalam memilih hari terbaik. Tuntutan untuk mengikuti kebiasaan tersebut disebabkan atas dasar pemahaman bahwa agama yang masyarakat yakini yaitu Islam juga menganjurkan hal yang sama. Tujuan dari mengikuti kebiasaan itu adalah agar acara perkawinan mendatangkan kebaikan, kemudahan, dan kelancaran acara tersebut, dengan harapan peristiwa perkawinan yang dilangsungkan tersebut dalam menjalaninya kelak mendatangkan kebaikan dalam kehidupan berumah tangga, kemudahan rezeki, dan langgeng hingga anak cucu.

Hari terbaik bagi masyarakat Bugis Kabupaten Bone untuk melangsungkan perkawinan adalah di bulan Syawwal setelah hari raya Idul Fitri, sehingga kawing soro' akan banyak ditemukan di bulan tersebut. Momen tersebut juga bertepatan dengan banyaknya keluarga yang akan terlibat membantu dan turut hadir dalam acara perkawinan, sebab sebagian besar kerabat (keluarga) yang berada di perantauan biasanya kembali ke kampung halaman untuk berlebaran.

\section{Kekurangan Dana}

Salah satu yang menjadi alasan dilaksanakannya kawing soro' dalam masyarakat Bugis Kabupaten Bone adalah kurangnya anggaran yang dimiliki oleh pengantin laki-laki, sebab dalam pesta perkawinan masyarakat bugis membutuhkan anggaran yang tidak sedikit. Pihak pengantin laki-laki akan meminta kepada pihak perempuan pada saat acara mappettu ada agar pesta perkawinan dilaksanakan setelah panen raya, atau dana yang dibutuhkan untuk kegiatan acara di hari akad nikah (esso akkalabinengeng) sudah tersedia dan dianggap cukup.

\section{Kawin Kembar}

Kawing soro' dilaksanakan jika dalam 1 (satu) keluarga terdapat 2 (dua) anak yang akan dinikahkan atau kawin kembar. Dalam kepercayaan masyarakat pernikahan tidak boleh dilakukan dalam satu waktu yang bertepatan sebab dikhawatirkan salah 
satu di antara mereka akan celaka atau suatu saat nanti pengantin akan mendapatkan musibah dan makurang dalle (kesulitan dalam penghasilan). Sehingga salah satu dari anaknya kawing soro' dilaksanakan sebagai tolak bala'(menghindari musibah).

Pada dasarnya perkawinan harus terlahir dari kesepakatan bersama 2 (dua) pihak keluarga besar, begitu pun dengan kawing soro' harus ada kesepakatan dari keluarga yang akan melangsungkan perkawinan. Bagi masyarakat Bugis Kabupaten Bone, selama kawing soro' tidak bertentangan dengan nilai-nilai agama atau bahkan baik menurut agama (hukum islam) maka alangkah baiknya jika akad nikah dilakukan terlebih dahulu. Namun kepatuhan masyarakat Bugis terhadap adat dan agama dilakukan secara bersamaan dan kedudukannya sama kuatnya, dalam konsep pangngadereng (social regulation) terdiri atas 5 (lima) unsur yang saling mendukung dan mengukuhkan, 2 (dua) diantaranya adalah ade' (adat) dan sara' (syariat Islam). ${ }^{8}$

\section{Hukum Perkawinan Islam dalam Masyarakat Bugis}

Tujuan yang luhur dari berlangsungnya suatu pernikahan adalah agar melaksanakan perintah Allah dan Rasul-Nya dalam kehidupan berumah tangga, dan tuntutan agar diterapkan dalam kehidupan berumah tangga tersebut berdasarkan anjuran agama hukumnya wajib. Oleh sebab itu, bagi seseorang yang akan membina kehidupan rumah tangga yang harmonis dan sesuai dengan tuntunan ajaran agama, Islam telah menetapkan beberapa kriteria dalam memilih calon pasangan yang ideal. Kriteria tersebut paling tidak atau minimal harus kafa'ah atau kufu' (sepadan atau setara), berakhlak karimah (shalih/shalihah) dan tidak fasik.

Beberapa kriteria di atas sepertinya tidak menjadi perhatian dan menjadi syarat utama dalam hal menetukan calon pasangan bagi anaknya. Dalam beberapa kasus tertentu di dalam masyarakat Bugis, para orang tua sibuk membicarakan uang panai, jabatan/pekerjaan, dan anak keturunannya siapa, bahkan sangat disayangkan jika yang terucapkan adalah yang penting anak tersebut kawin. Semua masalah itu mungkin saja merupakan pengaruh dari lingkungan yang buruk (materialistik) dan pada

\footnotetext{
${ }^{8}$ Ismail Suardi Wekke, "Islam dan Adat dalam Pernikahan Masyarakat Bugis di Papua Barat," Thaqafiyyat: Jurnal Bahasa, Peradaban dan Informasi Islam, Vol. 13, No. 2 (2014): 308.
} 
kenyataannya telah banyak terjadi pada orang tua. Serta kenyataan pula bahwa tidak sedikit orang tua yang selalu mengutamakan pada syarat banyaknya harta, kedudukan, status sosial serta keturunan dalam memilih pasangan hidup untuk anaknya. Sehingga pertimbangan tentang kufu' (sederajat, sepadan) hanya berdasar materi atau harta semata, dan pertimbangan-pertimbangan keyakinan/agama yang dimiliki oleh calon menantu nantinya tidak menjadi persoalan utama dalam memperhatikannya, padahal itu sangat penting.

Islam menekankan pentingnya kafa'ah atau kesamaan, kesepadanan atau sederajat dalam hal pernikahan, sebab dengan adanya kesamaan keyakinan antara lakilaki dan perempuan, maka upaya untuk menjadikan rumah tangga yang sakinah, mawaddah, dan rahmah, akan terwujud nantinya. Indikator kafa'ah menurut syari'at diukur dengan melihat kualitas iman dan taqwa serta akhlak, bukan melihat pada status sosial, harta, keturunan dan lainnya. Allah swt. memandang derajat manusia sama, baik itu orang Bugis ataupun bukan Bugis, miskin atau kaya. Tidaklah ada perbedaan derajat dari keduanya, melainkan derajat ketaqwanya kepada Allah swt. dan RasulNya.

Allah swt. berfirman dalam Q.S. al-Ḥujurāt/49:13:

Wahai manusia! Sungguh, Kami telah menciptakan kamu dari seorang laki-laki dan seorang perempuan, kemudian Kami jadikan kamu berbangsa-bangsa dan bersuku-suku agar kamu saling mengenal. Sungguh, yang paling mulia di antara kamu di sisi Allah ialah orang yang paling bertaqwa. Sungguh, Allah Maha Mengetahui, Mahateliti. ${ }^{9}$

Ayat tersebut dipahami bahwa tidak ada penghalang bagi umat Islam baik lakilaki atau perempuan selama mereka sekufu' untuk melangsungkan pernikahan. Adalah wajib bagi orang tua, bapak/ibu, kakek/nenek, paman/tante, khususnya muslim/ muslimah yang mengutamakan dunia semata dan masih mempertahankan adat istiadat yang bertentangan dengan ajaran Islam untuk meninggalkannya dan kembali kepada ajaran Alquran dan Sunnah Nabi, sebagaimana sabda Rasulullah saw.:

${ }^{9}$ Iwan Setiawan dan Agus Subagio (ed.), Al-Qur'an ul Karim: Tahfiz Junior (Bandung: Cordoba, 2018),517. 
Perempuan itu dinikahi karena empat hal, karena hartanya, karena keturunannya, karena kecantikannya dan karena agamanya. Maka pilihlah karena agamanya, niscaya kamu akan beruntung. ${ }^{10}$

Hadis tersebut menjelaskan bahwa pada umumnya wanita dipilih untuk dinikahi seorang laki-laki (begitu pula sebaliknya) karena empat hal, yaitu harta, keturunan, kecantikan dan agama. Nabi Muhammad saw. menganjurkan agar memilih yang baik agamanya. Memilih yang shalih/shalihah karena wanita shalihah adalah sebaik-baik perhiasan dunia dan dapat selamat dunia dan akhirat. Namun, apabila wanita dipilih karena cantik, atau memiliki harta yang banyak, atau karena alasan lainnya, tetapi memiliki kekurangan dalam hal pengetahuan agamanya, maka laki-laki boleh menikahinya, sebab para ulama membolehkan hal tersebut dan hukum pernikahannya tetap sah.

Allah swt. dalam Q.S. al-Nūr/24: 26 berfirman:

Perempuan-perempuan yang keji untuk laki-laki yang keji, dan laki-laki yang keji untuk perempuan-perempuan yang keji (pula). Sedangkan perempuan-perempuan yang baik untuk laki-laki yang baik dan laki-laki yang baik untuk perempuanperempuan yang baik (pula)....

Seorang laki-laki yang hendak ingin menikah sebaiknya memilih perempuan yang shalihah, demikian pula seorang perempuan sebaiknya memilih untuk menikah dengan laki-laki yang shalih. Sebagaimana Allah swt. berfirman dalam Q.S. al-Nisā'/4: 34:

...Maka perempuan-perempuan yang shalihah adalah mereka yang taat (kepada Allah) dan menjaga diri ketika (suaminya) tidak ada, karena Allah telah menjaga (mereka).... ${ }^{12}$

Dalam masyarakat Bugis di Kabupaten Bone, ajaran-ajaran agama sudah kuat diterapkan dalam hal pelaksanaan pernikahan, sebab secara filosofis tradisi diketahui tidak bertentangan dengan ajaran atau syariat Islam. Namun dengan adanya kawing soro', tradisi tersebut terkesan ditinggalkan dan disisi lain hukum Islam diterapkan. Agama dan budaya dalam kehidupan masyarakat tidak dapat dipisahkan dan merupakan bagian dari multikulturalis di Indonesia. Sebagaimana dijelaskan oleh Rizal

\footnotetext{
${ }^{10}$ Anie Mahmudah, "Memilih Pasangan Hidup dalam Perspektif Hadits (Tinjauan Teori dan Aplikasi," Diya Al-Afkar, Vol. 4. No. 01 Juni 2016: 90, http://dx.doi.org/10.24235/diyaafkar.v4i01.886

${ }^{11}$ Setiawan dan Subagio. Tahfiz Junior, 352.

${ }^{12}$ Ibid. 84 ,
} 
bahwa keragaman budaya yang plural berkaitan dengan kesadaran sosial masyarakat dalam mengespresikan budaya yang dianutnya. ${ }^{13}$

Pernikahan atau kawing soro' yang dilakukan oleh sebagian masyarakat di Kabupaten Bone tidaklah dapat diuraikan kapan peristiwa semacam ini berasal-mula dan keluarga siapa yang memulainya. Akan tetapi kawing soro' dipahami dan diterima oleh masyarakat, dan tuntutan akan kebutuhan kawing soro' oleh masyarakat harus dipenuhi untuk dilaksanakan. Dasar hukum tertulis kawing soro', baik itu regulasi dari pemerintah daerah, ketetapan Fatwa Majelis Ulama Indonesia (MUI) Kabupaten Bone, ataupun Dewan Adat, tidak dapat ditemukan dalam bentuk lembaran tertulis. Ini adalah bukti bahwa adanya sistem hukum tidak tertulis yang mempengaruhi dan menjadi kebiasaan masyarakat.

Dalam kajian ilmu sosial, teoretisasi mengenai bagaimana interdependensi antara tradisi masyarakat yang dianggap "non-agama" dengan nilai-nilai ajaran agama sudah dikerjakan dan sudah menjadi diskursus akademik, ${ }^{14}$ akan tetapi kehidupan sebuah masyarakat dipastikan memiliki suatu tradisi, yaitu yang secara sederhana didefenisikan dengan sesuatu yang diturunkan dan dikerjakan dari masa lalu ke masa kini". ${ }^{15}$ Ada nilai, kebiasaan dan adat istiadat masyarakat yang dipraktikkan bahkan juga dilanggengkan oleh masyarakat yang telah mereka terima dari masa lalu atau dari nenek moyangnya sampai dengan masa paling akhir, nilai tersebut meliputi norma, bahkan juga hukum. ${ }^{16}$

Pada dasarnya ada tiga macam sistem hukum yang merupakan konsekuensi dari pluralitas sistem hukum yang ada dan yang berlaku di Indonesia untuk dianut oleh masyarakat, termasuk masyarakat di Kabupaten Bone: ${ }^{17}$

Pertama, dilihat dari segi pluralitas jenis masyarakat dapat dikatakan bahwa sistem hukum yang berlaku sejak zaman primitif yang merupakan kebiasaan atau adat istiadat menjadi suatu ketentuan yang diyakini bersama untuk

\footnotetext{
${ }^{13}$ Rizal Darwis, "Hukum Islam dalam Multikulturalis Pluralitas di Indonesia," Zawiyah: Jurnal Pemikiran Islam, Vol. 3, No. 1 (2017): 112, http://dx.doi.org/10.31332/zjpi.v3i1.712

${ }^{14}$ Michael Golsenan dalam Ahmad Qodri A Azizy, Eklektisisme Hukum Nasional: Kompetisi antara Hukum Islam dan Hukum Umum (Yogyakarta: Gama Media, 2002), 181.

${ }^{15}$ Edward Shils dalam Azizy, Hukum Umum 182.

${ }^{16}$ Ibid., 182.

${ }^{17}$ Ibid., 109-110.
} 
dipatuhi. Kebiasaan atau adat istiadat ini disebut hukum adat atau hukum kebiasaan (customery law) atau hukum yang hidup di masyarakat (living law). Kedua, dari segi agama, sudah pasti ada nilai-nilai agama yang telah diyakini bersama dan tersistematis dalam kehidupan masyarakat dan mengatur hubungan atar-warga masyarakat, oleh karena sebagian besar beragama Islam maka hukum Islam merupakan salah satu sistem hukum yang berlaku ditengahtengah masyarakat, dan hukum Islam ini bergerak dinamis sebagai hukum yang harus sanggup memberi jawaban terhadap perubahan sosial, sehingga tidak diharuskan selalu mengacu pada kitab-kitab fiqh klasik.

Ketiga, sebagai negara yang pernah dijajah selama kurun waktu 350 tahun, jelaslah bahwa negara penjajah membawa sistem hukumnya untuk diterapkan kepada masyarakat yang dijajah, ini yang kemudian kita sebut dengan sistem hukum belanda atau sistem hukum barat.

Beberapa sistem hukum di atas disadari oleh masyarakat Bugis Kabupaten Bone mempunyai pengaruh yang signifikan termasuk banyaknya pengaruh yang datang dari kaidah agama/ hukum Islam. tujuan dari kaidah agama adalah agar manusia menjadi sempurna, agar tidak ada manusia menjadi jahat. Kaidah agama ditujukan kepada iman atau sikap batin manusia sebagai individu, sikap batinlah yang disentuh, yang dinilai.

Adapun hukum-hukum perkawinan dalam masyarakat Bugis Kabupaten Bone banyak dipengaruhi dan mengikuti hukum perkawinan Islam. Perkawinan dalam agama dikenal dengan istilah nikah yang bermakna suatu perjanjian atau akad yang dilakukan seorang laki-laki dan perempuan untuk menghalalkan hubungan kelamin antara kedua belah pihak dengan tujuan untuk mewujudkan kebahagiaan hidup yang diliputi oleh rasa kasih sayang dan ketentraman dengan ketentuan-ketentuan yang diridhai Allah. ${ }^{18}$ Dengan adanya perkawinan maka mereka memiliki hak dan kewajiban, saling memiliki, saling menjaga, saling membutuhkan dalam suasana saling mencintai hingga terwujudnya keluarga yang harmonis. ${ }^{19}$ Perkawinan (kawing) dan pernikahan (nikkah) adalah dua peristilahan yang sama artinya. Perkawinan merupakan sunnatullah dan merupakan jalan yang ditetapkan Allah swt. untuk manusia sebagai cara untuk beranak-berkembang dalam melestarikan kehidupannya. ${ }^{20}$

\footnotetext{
${ }^{18}$ Soemiyati, Hukum Perkawinan Islam dan Undang-Undang Perkawinan (Undang-Undang No. 1, Tahun 1974 tentang Perkawinan) (Yogyakarta: Liberty, 1982), 8.

${ }^{19}$ Sayuti Thalib, Hukum Kekeluargaan Indonesia Berlaku Bagi Umat Islam (Jakarta: UI Press, 1986), 5.

${ }^{20}$ Al-Sayyid Sabiq dan Mahyuddin Syaf, Fikih Sunnah (Bandung: Ma’arif, 1986), 477.
} 
Sebagai sebuah sunattulah maka perkawinan hendaknya dibina dalam rangka pelengkap ibadah manusia kepada Allah swt., yaitu pernikahan memberikan motivasi bagi suami istri untuk senantiasa meningkatkan ketakwaan dalam menjalankan ajaranajaran agama yang diperintahkan dalam Alquran dan hadis Rasulullah saw.

\section{Kawing Soro dalam Pendekatan al-'Adah al-Muhakkamah}

Aisyah ra. menceritakan bahwa: "Sesungguhnya pernikahan pada masa jahiliyah ada 4 (empat) macam, salah satunya adalah pernikahan yang dilakukan sebagaimana yang dilaksanakan oleh masyarakat saat ini, yaitu seorang laki-laki mendatangi perempuan atau anak gadis untuk meminangnya kepada walinya, lalu laki-laki memberikan mahar kepada perempuan dan kemudian menikahinya". Berdasar dari riwayat ini, diketahui bahwa adat atau kebiasaan manusia yang tidak bertentangan dengan ajaran Islam dan adab-adab Islam, maka Islam membolehkan. Oleh karena itu, adat dan budaya masyarakat Arab yang sudah dilakukan sebelum datangnya Islam tidak dihapus seluruhnya oleh Nabi Muhammad saw., namun hanya melarang kebiasaan atau adat yang mengandung unsur syirik, seperti pemujaan kepada leluhur dan nenek moyang serta budaya-budaya yang bertentangan dengan syariat Islami, sehingga dapat disimpulkan bahwa adat istiadat atau kebiasaan dapat dilakukan selama tidak bertentangan dengan ajaran dalam Islam. Sebaliknya, jika dianggap bertentangan dengan ajaran Islam maka hukumnya haram. ${ }^{21}$

Hukum Islam termasuk hukum yang diterima dan hidup (living law) dalam masyarakat sejak kedatangannya di nusantara hingga sekarang. Bukan karena hukum Islam adalah entitas agama yang dianut oleh mayoritas warga Indonesia, akan tetapi dalam pengamalannya di beberapa daerah, ajaran Islam merupakan bagian tradisi atau kebiasaan masyarakat yang dianggap sakral. ${ }^{22}$ Adat secara etimologi berarti pengulangan, sehingga setiap sesuatu yang sudah terbiasa dilakukan tanpa diusahakan disebut sebagai adat, namun tidak dapat disebut sebagai adat untuk sesuatu yang baru

\footnotetext{
${ }^{21}$ https://almanhaj.or.id/2643-pandangan-islam-terhadap-kebudayaan.html, diakses pada 12 Oktober 2019.

${ }^{22}$ Muhammad Roy Purwanto, Atmathurida dan Giyanto, "Hukum Islam dan Hukum Adat Masa Kolonial: Sejarah Pergolakan antara Hukum Islam dan Hukum Adat Masa Kolonial Belanda," An-Nur: Jurnal Studi Islam, Vol. 1, No. 2 (2005): 6.
} 
dilakukan satu kali. Imam al-Ghazali dalam Kitab al-Mustașfa mendefenisikan 'urf adalah suatu pengamalan yang berlaku dan menjadi satu ketetapan yang bersandar pada apa saja yang dianggap baik oleh akal serta dapat diterima oleh manusia normal. ${ }^{23}$ Hal ini harus dipahami bahwa tidak setiap kebiasaan disebut adat, suatu kebiasaan bisa dikatakan adat apabila dilakukan secara ajeg dan diyakini oleh masyarakat sebagai hukum yang harus dipatuhi. Adat juga merupakan tingkah laku yang oleh dan terjadi dalam suatu masyarakat (akan, sedang, atau sudah) diadatkan.

Kearifan lokal atau budaya masyarakat yang dijadikan sebagai sumber hukum Islam pada dasarnya bukanlah merupakan hal baru, selain memang dikenal dalam kaidah ushul fiqh (al-adah al-muhakkamah) juga kaitan antara adat dan hukum Islam di Indonesia yang tercatat dalam sejarah yang panjang. Kemunculan teori receptio in complexu oleh Van Den Berg yang mengungkap kenyataan hukum yang berlaku di masyarakat Indonesia pada masa pemerintahan Hindia Belanda adalah hukum Islam, kemudian teori tersebut dibantah oleh teori receptie yang menjelaskan bahwa hukum yang diakui di Indonesia adalah hukum adat, hukum Islam hanya atau bisa berlaku jika diterima oleh hukum adat. ${ }^{24}$ Akan tetapi teori receptie a contrario berpandangan bahwa pada masyarakat Indonesia ketentuan yang berlaku adalah hukum Islam, adapun hukum adat boleh berlaku kalau tidak bertentangan dengan hukum Islam. ${ }^{25}$

Berdasar pada sejarah yang dikisahkan 'Aisyah dan dialektika teori di atas, kenyataan masyarakat Bugis Kabupaten Bone dengan keberadaan kawing soro' mengindikasikan bahwa hukum Islam menjadi dominan dan diutamakan dalam hal perkawinan saat ini. Subtansi dari pelaksanaan kawing soro' dalam masyarakat Bugis Kabupaten Bone adalah perkawinan itu sah menurut hukum agama (hukum Islam), kemudian banyaknya peristiwa serupa menjadikannya diterima dalam masyarakat sebagai cara baru atau jalan keluar dari masalah yang dihadapi agar hubungan dua

\footnotetext{
${ }^{23}$ Ahmad Fahmi Abu Sinnah, الاسلامى التشريع فى نظرية عرض :الفقهاء رأى فى والعادة العرف (Mesir: Maktabah Al Azhar, 1947), 10.

${ }^{24}$ Ismail Suny, "Hukum Islam dalam Hukum Nasional: Suatu Pandangan dari Hukum Tata Negara," PidatoIlmiah, disampaikan pada upacara Wisuda Sarjana/Sarjana Muda Universitas Muhammadiyah Jakarta Tahun 1987 pada tanggal 22Juni1987 di Balai Sidang Jakarta, 352.

${ }^{25}$ Abdul Manan dalam Nurjihad, "Pembaharuan Hukum Islam di Indonesia: Studi Kasus CLD Kompilasi Hukum Islam,” Jurnal Hukum IUS QUIA IUSTUM, Vol. 11, No. 27 (2004): 113.
} 
manusia yang berbeda jenis menjadi sah, paling tidak perkawinan itu sah menurut agama (hukum Islam).

Kawing soro' dalam masyarakat Bugis dilaksanakan dengan tidak mengikuti tahapan yang pada dasarnya sudah menjadi tradisi pula. Salah satu dari tahapan pra nikah yang sakral adalah mappacci atau mappaccing, yaitu membersihkan dan mensucikan (membersihkan raga dan mensucikan jiwa) calon pengantin yang akan melangsungkan akad nikah, kegiatan mappacci ini dilaksanakan pada malam sebelum akad nikah. Tujuan pelaksanaan mappacci agar calon pengantin (baik laki-laki maupun perempuan) siap lahir batin dengan hati yang suci, bersih, serta memiliki keikhlasan dalam mengarungi kehidupan rumah tangga, dengan mappacci tersebut dapat membersihkan segalanya, baik itu mappaccing ati (membersihkan hati), mappaccing nawa-nawa (membersihkan fikiran), mappaccing pangkaukeng (membersihkan/ baik tingkah laku/ perbuatan), mappaccing ateka (membersihkan itikad). ${ }^{26}$

Mappacci, jika berdasar pada penjelasan di atas, adalah ritual yang sarat akan makna/nilai dan mekanismenya tidak bertentangan dengan kaidah agama/ hukum Islam, bahkan dari rangkaian dalam kegiatan mappacci oleh masyarakat dianggap mendatangkan keberkahan (bernilai ibadah), adalah Massikkiri (berzikir), mappenre temme (khatam Alquran) dan mabbarasanji (membaca Kitab al-Barazanji). Oleh karena itu, masyarakat Bugis Kabupaten Bone menyepakati bahwa pelaksanaan mappacci hukumnya wajib untuk dilakukan sebelum akad nikah, sebab didalamnya terdapat banyak hikmah.

\section{E. Kesimpulan}

Kebiasaan-kebiasaan yang dianggap sarat akan makna spiritual oleh masyarakat, menjadi tidak bernilai setelah adanya sebagian masyarakat Bugis kabupaten Bone yang melakukan kawing soro'. Di sisi lain, kawing soro' menjadi wajib dilaksanakan apabila dikhawatirkan terjadinya zina, dalam arti lain bahwa kawing soro' bisa saja dilakukan jika ada kondisi yang memaksakan atau darurat.

${ }^{26}$ Siti Syuhada, Apdelmi Apdelmi, dan Abd Rahman, "Adat Perkawinan Suku Bugis di Kota Jambi: Studi tentang Perubahan Sosial,” Titian: Jurnal Ilmu Humaniora, Vol. 3, No. 1 (2019): 130. 
Masyarakat Bugis Kabupaten Bone yang melaksanakan kawing soro' pada dasarnya ingin melaksanakan perintah Allah dan Rasulnya, namun tidak di pahami oleh masyarakat bahwa pasangan yang melakukan kawing soro', sang suami wajib membayar mahar meskipun hanya memberikan separuhnya dan Istri boleh menolak memberikan hak-hak suami seperti bergaul dan melakukan hubungan kelamin sebelum Istri menerima pendahuluan mahar yang ditetapkan. Hal ini perlu diketahuii oleh masyarakat Bugis Kabupaten Bone agar hak dan kewajiban suami dan istri dalam berhubungan menjadi jelas dan tidak lagi menimbulkan keraguan didalamnya.

\section{F. Daftar Pustaka}

Darwis, Rizal. "Hukum Islam dalam Multikulturalis Pluralitas di Indonesia," Zawiyah: Jurnal Pemikiran Islam, Vol. 3, No. 1 (2017), http://dx.doi.org/10.31332/ zjpi.v3i1.712

Darwis, Rizal. Hak Nafkah Batin Isteri dalam Perkawinan. Cet. 1; Gorontalo: Sultan Amai Press, 2015.

Golsenan, Michael dalam Ahmad Qodri A Azizy, Eklektisisme Hukum Nasional: Kompetisi antara Hukum Islam dan Hukum Umum. Yogyakarta: Gama Media, 2002.

Mahmudah, Anie. "Memilih Pasangan Hidup dalam Perspektif Hadits (Tinjauan Teori dan Aplikasi," Diya Al-Afkar, Vol. 4. No. 01 Juni 2016: 90, http://dx.doi.org/10.24235/diyaafkar.v4i01.886

Manan, Abdul dalam Nurjihad, "Pembaharuan Hukum Islam di Indonesia: Studi Kasus CLD Kompilasi Hukum Islam," Jurnal Hukum IUS QUIA IUSTUM, Vol. 11, No. 27 (2004).

Nonci. Upacara Pernikahan Masyarakat Bugis. Makassar: CV Aksara, 2006.

Purwanto, Muhammad Roy, Atmathurida dan Giyanto, "Hukum Islam dan Hukum Adat Masa Kolonial: Sejarah Pergolakan antara Hukum Islam dan Hukum Adat Masa Kolonial Belanda," An-Nur: Jurnal Studi Islam, Vol. 1, No. 2 (2005).

Republik Indonesia. Kompilasi Hukum Islam. Jakarta: Mahkamah Agung Republik Indonesia, 2004.

Republik Indonesia. Undang-Undang Nomor 1 Tahun 1974 tentang Perkawinan. Jakarta: Alda/Pentja, 1974.

Rusli, Muh. "Reinterpretasi Adat Pernikahan Suku Bugis Sidrap Sulawesi Selatan," Karsa, Vol. 20, No. 2 (2012.

Sabiq, Al-Sayyid dan Mahyuddin Syaf, Fikih Sunnah. Bandung: Ma’arif, 1986). 
Sinnah, Ahmad Fahmi Abu. التشـريع فى نظرية عرض :الفقعاء رأى فى والعادة العرف الاسلامى (Mesir: Maktabah Al Azhar, 1947.

Setiawan, Iwan dan Agus Subagio (ed). Al-Qur'anul Karim:Tahfiz Junior. Bandung: Cordoba, 2018.

Soemiyati. Hukum Perkawinan Islam dan Undang-Undang Perkawinan (UndangUndang No. 1, Tahun 1974 tentang Perkawinan). Yogyakarta: Liberty, 1982.

Suny, Ismail. "Hukum Islam dalam Hukum Nasional: Suatu Pandangan dari Hukum Tata Negara," Pidato Ilmiah, disampaikan pada upacara Wisuda Sarjana/Sarjana Muda Universitas Muhammadiyah Jakarta Tahun 1987 pada tanggal 22Juni1987 di Balai Sidang Jakarta.

Syuhada, Siti, Apdelmi, dan Abd Rahman, "Adat Perkawinan Suku Bugis di Kota Jambi: Studi tentang Perubahan Sosial," Titian: Jurnal Ilmu Humaniora, Vol. 3, No. 1 (2019).

Thalib, Sayuti. Hukum Kekeluargaan Indonesia Berlaku Bagi Umat Islam. Jakarta: UI Press, 1986.

Wekke, Ismail Suardi. "Islam dan Adat dalam Pernikahan Masyarakat Bugis di Papua Barat," Thaqafiyyat: Jurnal Bahasa, Peradaban dan Informasi Islam, Vol. 13, No. 2 (2014).

Widyawati, "Makna Tradisi Uang Panai dalam Adat Pernikahan Suku Bugis di Sungai Guntung Kecamatan Kateman Kabupaten Indragiri Hilir Provinsi Riau," JOM FISIP, Vol. 5, Edisi 11 (2018).

https://almanhaj.or.id/2643-pandangan-islam-terhadap-kebudayaan.html 